\title{
THE DESTINY OF THE NATIONS IN REVELATION 21:1-22:5:
}

\author{
A RECONSIDERATION
}

\author{
Dave Mathewson
}

\begin{abstract}
Summary
There has been a variety of attempts to account for the presence of the nations in Revelation 21:1-22:5 and their inclusion in eschatological salvation, when their judgement and destruction has already been described in Revelation 19-20. Many scholars have suggested that John envisions the salvation of a segment of the nations, while the unbelieving meet their doom in the lake of fire. A few have suggested that the tension can be resolved by reference to universalism: ultimately even the wicked who are punished will be redeemed. One of the most significant attempts to account for the destiny of the nations is in the work of Bauckham, who suggests that John gives priority to the vision of salvation and envisions the conversion of the nations in fulfilment of OT expectations, while a few who refuse to repent will experience punishment. Through an examination of the key texts in Revelation 21:1-22:5, namely 21:3; 21:24; and 22:2, this article suggests that the tension between the judgement and salvation of the nations must be allowed to retain its full force. Neither side of the tension should be privileged over the other. The tension functions in a rhetorical manner: to present the options available to the nations, and to highlight the reversal of power structures and the absolute sovereignty of God.
\end{abstract}

\section{Introduction}

The question of the destiny of the nations in the canonical book of Revelation continues to puzzle interpreters of the Apocalypse. Commentators have failed to settle on the precise significance of John's portrait of the nations' inclusion in eschatological salvation, especially in the climactic vision of 21:1-22:5 where the destiny of the nations is articulated most clearly and receives its 'eschatological 
ultimacy'. ${ }^{1}$ More specifically, how is the universal language in John's scenario of eschatological salvation to be construed? Does John envisage a mass conversion of the nations in the future to become the one true people of God and to worship the one true God, a conclusion which an initial reading of texts such as 21:3, 24-26; 22:2 (cf. 15:4) seems to invite, or do the nations in this final vision consist only of a segment of the nations who have been converted, while the unbelieving of the nations have met their doom in the lake of fire? R.J. Bauckham frames the question in this way: 'Does Revelation expect the nations to be won from satanic deception and converted to the worship of God, or does it expect them to persist under rebellion until they perish under God's final judgment'?2

Part of the difficulty is that, as Bauckham recognises, " $[t]$ he evidence seems to point both ways and commentators seem unable to give equal weight to all of it' ${ }^{3}$ How does the reader account for the derogatory portrayal of the nations as those who worship the beast and resist God's rule, while now in chapters 21-22 they take their place in the New Jerusalem? Statements of both universal judgement and universal salvation are juxtaposed throughout Revelation in seemingly conflicting fashion. Specifically, how does one account for the presence of the nations and kings in 21:24-26;22:2c following the portrayal of their judgement in texts such as $6: 15 ; 14: 7-20 ; 16: 16-21$ and their consummate destruction narrated in 19:17-21;20:7-10, 11-15? D.E. Aune comments on 21:24 that

[t]here is, then, an apparently striking inconsistency in the eschatological scenario of Revelation introduced by this verse (and v. 26) since 19:17-21 and 20:7-10 narrate the destruction of the kings of the earth and their armies ..., and yet here in vv. 24-27, nations and kings of the earth still exist. ${ }^{4}$

The questions posed by the inclusion of the nations in eschatological salvation in 21:1-22:5 are profound, and have engendered a variety of proposed solutions in an attempt to account for this phenomenon.

1 R.J. Bauckham, The Theology of the Book of Revelation (Cambridge: CUP, 1993), p. 103.

2 R.J. Bauckham, The Climax of Prophecy: Studies on the Book of. Revelation (Edinburgh: T. \& T. Clark, 1993), pp. 241-42.

3 Bauckham, Climax, p. 242.

4 D.E. Aune, Revelation 17-22 (WBC 52c; Nashville: Thomas Nelson, 1998), p. 1171. Cf. J. Massyngberde Ford, Revelation (AB 38; Garden City: Doubleday, 1975), pp. 337-38. Cf. Bauckham, Climax, pp. 308-309. 


\section{Recent Proposals on the Conversion of the Nations}

First, some merely note the tension but are reticent to give an account for how the tension between John's visions of universal judgement and salvation is to be handled. ${ }^{5}$ Second, others have strongly suggested that the emergent nations in 21:1-22:5 consist of those who have been redeemed out of the nations throughout the history of the church (cf. 5:9; 7:9), so that John's vision explicates the transcultural nature of the church. As U.B. Müller states, 'Die Universalität von Vers 24-27 liegt in der Ausrichtung auf die Kirche aus Juden und Heidenvölkern' ${ }^{6}$ Likewise, according to the recent commentary by G.K. Beale, the kings and nations of 21:24 'are best identified with those in 5:9-10 who were "bought ... from every tribe and tongue and people and nation", were made a "kingdom", and reigned as kings throughout the church age' ${ }^{7}$ These will replace the kings and nations who have rendered allegiance to Babylon and the beast. ${ }^{8}$ As Beale concludes,

21:24-26 represents the peoples redeemed from the nations throughout the inaugurated end-time age of the church (including the very end of the age), who now inherit the earth and reign in place of the peoples who have shown allegiance to Babylon and the beast. ${ }^{9}$

Third, M. Rissi has advocated a novel interpretation which construes the nations and kings of the earth as those who are spatially outside of the eschatological Jerusalem and who previously have met their demise in the lake of fire. ${ }^{10}$ Yet through his reinterpretation of the pilgrimage of the nations motif in Isaiah 60 , John constructs a striking picture of the redemption of God's former enemies from the lake of

5 Massyngberde Ford, Revelation, pp. 337-38.

6 U.B. Müller, Die Offenbarung des Johnannes (ÖTKNT, 19; Gütersloh: Gerd Mohn, 1984), p. 362.

7 G.K. Beale, The Book of Revelation (NIGTC; Grand Rapids/Carlisle: Eerdmans/Paternoster, 1999), p. 1097. At the same time Beale would also include those who are converted from the nations at the very end of the age along with the redeemed throughout the church age (p. 1101). Cf. also M. Kiddle, The Revelation of Saint John (MNTC; London: Hodder and Stoughton, 1940), p. 439; R.H. Gundry, 'The New Jerusalem: People as Place, Not Place for People', NovT 29 (1987), 263.

8 So Kiddle, Revelation, pp. 438-39; Gundry, 'People as Place', p. 263; Müller, Die Offenbarung, p. 362; Beale, Revelation, pp. 1047, 1097-1101.

9 Beale, Revelation, p. 1101.

10 M. Rissi, The Future of the World: An Exegetical Study of Rev. 19:11-22:15 (SBT 2/23; London: SCM, 1972), pp. 68, 71-74, 78. Cf. J.A. du Rand, 'The Imagery of the Heavenly Jerusalem (Revelation 21:9-22:5)', Neot 22 (1988), 77-78. 
fire and their entrance into the New Jerusalem through its perpetually open gates (21:25). In this way John envisions the 'redemption of the foes of Christ par excellence'. 11

In a similar vein, J. Vogelgesang attempts to wrestle with the universal redemption of the nations within the context of depictions of universal judgement and destruction. ${ }^{12}$ According to his understanding of John's radical democratisation of the OT, Vogelgesang, like Rissi, sees John as featuring the entrance of God's former enemies into the New Jerusalem. Following their judgement John envisions a constant flow of the former enemies from the lake of fire into the New Jerusalem, as he attempts to balance the contradictory concerns of the holiness/universality of the New Jerusalem and judgement/salvation of the nations. Similar to the previous view, both Rissi and Vogelgesang take the language of judgement and destruction seriously, but then suppose that the author of the vision makes the bold move of envisioning the conversion and transformation of those who have previously experienced final judgement.

The most recent and substantive attempt to broach the question of the conversion of the nations in Revelation is the work of Bauckham. Bauckham has provided somewhat of a mediating position between the above approach which lands only the redeemed from the nations, the church, in the New Jerusalem, and the approach of Rissi and Vogelgesang, which expects the universal conversion of those who have been destroyed in judgement. ${ }^{13}$ Bauckham endeavours to take both the indicators of universal judgement and salvation seriously. 'Revelation sets side by side, without qualifying one by the other, the two possible outcomes: the conversion of the nations and their inclusion in God's kingdom or the judgment of the unrepentant nations'. ${ }^{14}$ The witness of the Lamb and the Martyrs leads the nations either to repentance/conversion or rebellion/punishment. ${ }^{15}$ But in Bauckham's view the full inclusion of the nations receives

11 Rissi, Future of the World, p. 78.

$12 \mathrm{~J}$. Vogelgesang, 'The Interpretation of Ezekiel in the Book of Revelation' (Unpublished Ph.D. Thesis, Harvard University, 1985), pp. 104-106. Cf. D. Georgi, 'Die Visionen vom himmlischen Jerusalem in Apk 21 und 22', in D. Lührmann and G. Strecker (eds.), Kirche (FS G. Bornkamm; Tübingen: J.C.B. Mohr [Siebeck], 1980), pp. 351-72, upon which much of Vogelgesang's work depends.

13 Bauckham, Climax, pp. 238-337; idem, Theology, pp. 94-104, 136-40.

14 Bauckham, Theology, p. 104.

15 Bauckham, Theology, pp. 104-106. 
'theological priority' in John's climactic vision and supersedes the visions of judgement. ${ }^{16}$

Bauckham treats in detail not only 21:1-22:5, but also previous passages (esp. 10;11:3-13; 14 and 15:2-4) in Revelation which anticipate $21: 1-22: 5$, where the motif of the conversion of the nations reaches its climactic development. According to Bauckham, two strands of language and symbolism permeate John's final vision. The gates, which include the names of the twelve tribes of Israel (21:13), and the foundations being inscribed with the names of the twelve apostles (21:14), along with the ubiquitous number twelve, point to the culmination of the history of Israel and the church as God's people in the New Jerusalem. Yet the universal elements embedded in John's final vision point to the redemption of the kings and nations which formerly belonged to Babylon and resisted God's rule. In addition to the programmatic statement in 21:3 ('they shall be his peoples

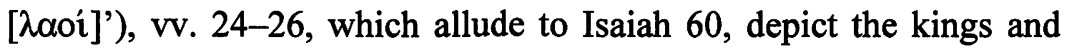
nations as entering the New Jerusalem and becoming the covenant people of God.

Bauckham argues that this combination of particularism and universalism is best explained by the OT expectations of the conversion of the nations finding its eschatological realisation in the full inclusion of the nations to become the people of God in the New Jerusalem. ${ }^{17}$ In his view this will transpire through the witnessing of the martyr church (11:3-13). ${ }^{18}$ As Bauckham states,

[t] he history of the covenant people - both of the one nation Israel and of the church which is redeemed from all nations - will find its eschatological fulfilment in the full inclusion of the nations in its own covenant privileges and promises. ${ }^{19}$

Thus, Bauckham solves the problem of the apparent tension between universal depictions of judgement and salvation by giving 'theological priority' to the latter. However, in a footnote he adds the caveat that not every last human being will be converted, for the warnings in $21: 8,27$ clearly preclude such a possibility, thus distancing himself

16 Bauckham, Climax, p. 310.

17 Bauckham, Climax, p. 313.

18 Bauckham, Climax, p. 310. On 11:3-13 more specifically see idem, Climax, pp. 273-83.

19 Bauckham, Climax, p. 139; idem, Theology, p. 104. 
from a thoroughgoing universalism of Rissi and the radical democratisation of Vogelgesang. ${ }^{20}$

\section{The Conversion of the Nations in Rev. 21:1-22:5}

While a thorough consideration of the topos of the conversion of the nations in the Apocalypse, and especially Bauckham's careful articulation of John's appropriation of this theme, would require a careful probing of a number of passages in Revelation, not least 10; $11: 3-13 ; 14$ and 15:2-4, all of which Bauckham carefully considers, the scope of this article is more circumscribed. It will focus specifically on the climactic vision of 21:1-22:5, since the theme of the conversion of the nations proves its 'eschatological ultimacy' in the vision of the New Jerusalem, and since the articulation of the theme in 21:1-22:5 completes the direction to which the previous passages in Revelation have all been pointing. ${ }^{21}$ The ensuing discussion will comprise a reconsideration of the conversion of the nations theme in 21:1-22:5 in light of the above approaches.

As Bauckham suggests, the most pressing challenge is to give equal weight to both the scenes of judgement and salvation. This article is in part a response to the important and innovative approach of Bauckham. While expressing areas of agreement, it will, however, suggest important qualifications to aspects of Bauckham's overall thesis. Most who engage the issue of the conversion of the nations in the Apocalypse point to $21: 3 ; 21: 24$; and $22: 2$ as salient. These texts will be examined in turn in an attempt to elucidate John's portrait of the destiny of the nations in 21:1-22:5.

\section{a) Revelation 21:3}

Although the term है $\theta v \eta$ ('nations') does not occur in 21.3, this verse provides an important starting point for our discussion. Through modification of the OT covenant formula (see below), John combines the language of God's commitment to his covenant people along with the universal language of hope for the conversion of the nations to become God's people. Consequently, 'this verse is programmatic for the whole account of the New Jerusalem that follows'. ${ }^{22} 21: 3$, which

20 Bauckham, Climax, p. 313 n. 100: 'Attempts to see Revelation as predicting universal salvation ... strain the text intolerably'. Cf. Müller, Die Offenbarung, p. 362.

21 Bauckham, Climax, p. 310; idem, Theology, p. 139.

22 Bauckham, Climax, p. 311. 
stands at the centre of a chiastic arrangement of 21:1-5a, commences an audition by a anonymous voice from the throne, providing a commentary on the vision of the New Jerusalem-Bride and its descent to the new creation in vv. 1-2.

A. New Heaven and New Earth (1a)

B. First Heaven and Earth have passed away (1b)

C. No more Sea (1c)

D. The New Jerusalem/Bride (2)

(shift from vision to audition)

D.' Dwelling of God with his Bride (3)

C.' No more pain and mourning $(4 a-c)$

B.' Former things have passed away (4d)

A.' All things made New (5a)

Revelation 21:3 highlights what is paramount in the entire vision: God's covenant dwelling with his people. Here John characteristically draws on the OT for his formulation (Ezk. 37:27-28; Zc. 2:10-11a [MT 2:14-15a]), and part of the issue regarding how Revelation conceives of the fate of the nations revolves around the way the author utilises the OT. ${ }^{23}$ Both of these OT texts alluded to in 21:3 incorporate an application of the covenant formula in an eschatological context. In John's adaptation of the OT covenant formula, two recognisable changes have occurred.

First of all, in contrast to the original restrictive application of the formula to God's covenantal dwelling with the nation Israel (Ezk.

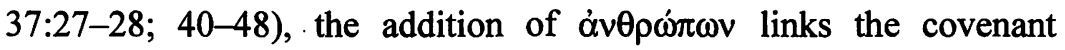
formula internally with the references to humanity in general throughout the rest of the book of Revelation (cf. 8:11; 9:6, 10, 15, 18, $20 ; 13: 13 ; 14: 4 ; 16: 8-9$ [bis], 21), so that the inclusion of humanity in 21:3 contrasts with their former subservience to the beast and

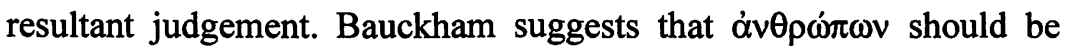
understood in the sense of the human race, since this is the sense that it commonly has elsewhere in Revelation. ${ }^{24}$ While the inclusion of $\dot{\alpha} v \theta \rho \omega i \omega v$ clearly indicates the universal extent of the covenant formula as Bauckham suggests so that 'humanity' is marked out as participating in the covenantal promise to God's people, John does not quantify his language so that it is difficult to determine precisely what John envisions. The reader of Revelation to this point, for whom the author has built up 'an extensive network of cross-references and

23 For further references to the covenant formula cf. Lv. 26:11-12; Je. 30:22; 31:1, 33; 32:38; Ezk. 36:28; 37:23; Zc. 8:8.

24 Bauckham, Climax, p. 311. 
allusions' 25 which have a cumulative effect and provide a contextual web for interpreting any given passage of Revelation, will also recall that significant portions of $\dot{\alpha} v \theta \rho \omega \dot{\pi} \omega v$ have perished under divine judgement $(8: 11 ; 9: 15,18)$. Thus, does the totality of humanity experience eschatological salvation, or only some who have survived previous judgements?

Significant also is the second transposition. There is now substantial agreement that the plural $\lambda \alpha o$ i ('peoples') found in $\$ \mathrm{~A}$ 0462030205020532062 constitutes the original reading, and that the variant $\lambda \alpha$ ó $\varsigma$ can be accounted for by a subsequent attempt to conform to the standard covenant formula and terminology (cf. Lv. 26:11-12; Je. 31:33; Ezk. 37:23, 27; Zc. 8:8). ${ }^{26}$ Though the term है $\theta v \eta$ does not appear in 21.3 , this crucial change has the effect of recalling the OT promises of the inclusion of the nations in the covenant privileges of the people of God. ${ }^{27}$

This is particularly clear in John's allusion to Zechariah 2:10-11a (MT vv. 14-15a), which expressly anticipates that 'Many nations (גוים) shall join themselves to the Lord on that day, and shall be my people (לעם); and I will dwell in your midst' (cf. Mi. 4:2). Thus, the limited horizon of John's Vorbild (Ezk. 37:26-27), which restricts membership in the people of God to national Israel, is now expanded along universal lines to include all peoples in line with OT prophetic promises of the inclusion of the nations in eschatological salvation. ${ }^{28}$

$25 \mathrm{~J}$. Webb Mealy, After the Thousand Years: Resurrection and Judgment in Revelation 20 (JSNTSup, 70; Sheffield: JSOT, 1992), p. 13.

26 Cf. Vogelgesang, 'Interpretation of Ezekiel', p. 84; P. Prigent, L'Apocalypse de Saint Jean (CNT, XIV; Lausanne: Delachaux \& Niestlé, 1981), pp. 320, 327; Aune, Revelation 17-22, p. 1110; Beale, Revelation, p. 1048; B.M. Metzger, $A$ Textual Commentary on the Greek New Testament (2nd edn; Stuttgart: UBS, 1994), p. 688; Bauckham, Climox, p. 310 . Contra H. Strathmann, ' $\pi$ '́ $1 \varsigma^{\prime}$ ', TDNT, VI, p. 533 n. 77.

27 Cf. Gn. 12:3; Pss. 22:27; 86:9; 96:7-9; Is. 2:2-4; 9:1; 11:9-10; 19:21, 25; 25:3, 6-8; 42:10-12; 45:22-23; 49:6; 55:5; 56:3-8; 60:3-5, 10, 11; 66:18-21, 23; Je. 3:17; Dn. 7:14; Am. 9:12; Mi. 4:1-3; Zp. 3:9; Zc. 2:10-11; 8:20-23; 14:16. Cf. Beale, Revelation, pp. 1046-47; Müller, Die Offenbarung, pp. 350-51.

28 Bauckham, Climax, pp. 310-11. John achieves this by two means. 1) John combines a narrowly focused text (Ezk. 37:26-27) with a more universal text (Zc. $2: 10-11$ ) based on similarity of vocabulary and motif (see G.K. Beale, 'Revelation', in D.A. Carson \& H.G.M. Williamson (eds.), It is Written: Scripture Citing Scripture: Essays in Honour of Barnabas Lindars [Cambridge: CUP, 1988], p. 328). 2) John reads the OT in light of the heilsgeschichtliche fulfilment in Christ. Thus, John's reading of Ezekiel has necessarily been carried out in interaction with other voices: other OT texts; the heilsgeschichtliche situation of fulfilment in Christ. Cf. further D. Mathewson, The Meaning and Function of the Old Testament in Revelation 21.1-22.5 (Ph.D. Thesis; University of Aberdeen, 1998), pp. 199-200. 
Moreover, what has gone unnoticed is that the plural $\lambda$ ooi in John's adaptation of the covenant formula in 21:3 may be accounted for by a deliberate contrast with 17:15, where $\lambda \alpha o$ i refers to the people who belong to the city Babylon in chapters 17-18.29 The importance of this observation is that John envisions the inclusion in the people of God of those who formerly belonged to Babylon and were inimical to God's kingdom (chs. 17-18). Once again, the reader is confronted with a tension between the rebellion and the conversion of the 'peoples' ( $\lambda \alpha o$ i) of the world. Though 21:3 does not explicitly refer to the conversion of the nations, nor provide the reader with details as to how the author envisions this taking place, the inclusion of the nations in the covenant privileges is clearly presupposed in 21:3 and is programmatic for the clearer development of this motif articulated in 21:24-26.

\section{b) Revelation 21:24}

The most crucial verse in the author's articulation of the conversion of the nations is $21: 24$, where John envisions the nations and kings of the earth coming to take up residence in the New Jerusalem, for it is here that the tension between the destruction/salvation of the nations and kings becomes most prevalent. Two crucial problems surface in analysing this text: 1) who are the nations and what is their relationship to the New Jerusalem? 2) How do we explain their presence in the New Jerusalem when their destruction has been narrated in chapters 19-20?

Who are the nations and what is their relationship to the New Jerusalem? In envisioning the inclusion of the nations and kings in the eschatological city John evokes the Völkerwallfahrt ('Pilgrimage of the Nations') motif from Isaiah $60 .{ }^{30}$ More specifically, Revelation 21:24 constitutes an allusion to Isaiah 60:3. ${ }^{31}$

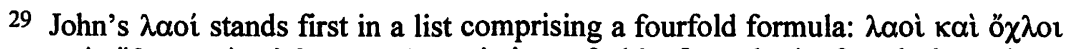

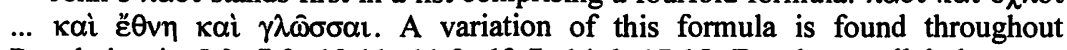
Revelation in $5: 9 ; 7: 9 ; 10: 11 ; 11: 9 ; 13: 7 ; 14: 6 ; 17: 15$. For the parallels between Revelation 17-18 and 21-22 see C. Deutsch, 'Transformation of Symbols: The New Jerusalem in $21^{1}-22^{5}, Z N W 78$ (1987), pp. 123-24.

30 The importance of this motif for Isaiah is evident from the fact that it frames the entire book: $2: 2-5 ; 66: 18-21$. For a treatment of this motif see $\mathrm{H}$. Wildberger, 'Die Völkerwallfahrt zum Zion: Jes. II 1-5', VT 7 (1957), pp. 62-81; G. von Rad, The Problem of the Hexateuch and Other Essays (trans. E. Trueman Dicken; Edinburgh and London: Oliver \& Boyd, 1965), pp. 232-42. Cf. Pss. 68:29; 72:9-11; 86:9; 102:21-22; Is. 11:10-11; 18:7; 49:22-23; Je. 3:17; Mi. 4:1-4; Zp. 3:9-10; Hg. 2:6-8; Zc. 8:20-23; 14:9, 16-19; 1 Enoch 90:30-36; Sib. Or. 3:772-73; T. Benj. 9:2; 1QM 12:13-15; Tob. 13:11; Pss. Sol. 17:30-35. Cf. $1 \mathrm{Ki}$. 


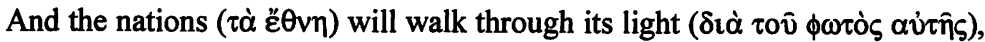

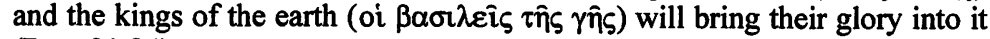
(Rev. 21:24).

Nations (גוים) shall come to your light (לאורך), and kings (ומלכים) to the brightness of your dawn (Is. 60:3).

However, John characteristically combines more than one text in his construct. The statement comprising Revelation $21: 24$, especially the second half, appears to be a synthesis of several elements which derive from Isaiah 60 regarding the kings and the nations. ${ }^{32}$
Rev. 21:24a
60:3: nations and kings are drawn to Jerusalem's light.
Rev. $21: 24 b$
60:5: the wealth of the nations comes to the city.
60:6: nations will come bearing gold and incense.
60:10: kings shall minister.
60:11: nations shall bring wealth and kings will come in procession.
60:16: Jerusalem will suck the milk of nations and the breasts of kings.

The primary feature highlighted in the Völkerwallfahrt in Isaiah 60 is the restoration of Jerusalem's wealth and glory in the future (vv. 3-16) as the nations function as 'bearers and bringers of all that is to glorify Zion in the new age ...', 33 although the notion of worship to God is not entirely absent, even if somewhat muted (cf. 60:6, 9, 14). The primary significance of this feature in Isaiah is to highlight the reversal that will ensue in the future: while the nations destroyed Jerusalem in the past, they will restore its wealth in the future; while the nations subjugated Israel in the past, they will serve them in the future.

In addition to this, John has also assimilated an allusion to Isaiah 2:2-5, a text linked to Isaiah 60:3 lexically (אור , הלך) and conceptually through the shared motif of the pilgrimage of the nations to Zion. As Bauckham has correctly observed, the באור of Isaiah 2:5

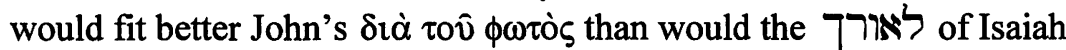
$60: 3 .{ }^{34}$ Isaiah 2:2-5 depicts the nations streaming to the mountain of

10:23-25. For the role of the nations in Isaiah see G. Davies, 'The Destiny of the Nations in the Book of Isaiah', in J. Vermeylen (ed.), The Book of Isaiah/Le livre d'Isaïa: Les oracles et leurs relectures. Unité et complexité de l'ouvrage (BETL, 81; Leuven: LUP, 1989), pp. 93-120.

31 For substantiation see Fekkes, Isaiah and Prophetic Tradititions, pp. 269-70; Bauckham, Climax, pp. 313-14; Beale, Revelation, pp. 1094-97.

32 Cf. A. Wikenhauser, Die Offenbarung des Johannes (RNT, 9; Regensburg: Friedrich Pustet, 1959), p. 159; Fekkes, Isaiah and Prophetic Traditions, p. 270.

33 C. Westermann, Isaiah 40-66 (OTL; London: SCM, 1969), pp. 359-60. Cf. N. Whybray, Isaiah 40-66 (NCB; London: Marshall, Morgan \& Scott, 1975), p. 231.

34 Bauckham, Climax, p. 314. 
the Lord to learn his ways and walk (נלכה) in his paths (vv. 2, 3). If this is the case, a text which originally addressed 'the house of Jacob' (2:5) now applies to the nations in Revelation 21:24. The semantic effect of reading $21: 24$ in light of Isaiah $2: 2-5$ is that the nations are not only drawn to the light of God and come to restore Zion's fortunes (Is. 60:3, 5, 6, 11), they also worship the true God and live according to his will (2:2-4) and become his people (2:5). In any case, John's choice of $\delta o ́ \xi \alpha$ as the express subject of the kings' activity (Rev. $21: 24)$ clearly connects the Völkerwallfahrt with John's vocabulary of worship $(1: 6 ; 4: 9,11 ; 5: 12,13 ; 7: 12 ; 11: 13 ; 14: 7 ; 16: 9 ; 19: 1$, 7; see $\delta \delta^{\prime} \xi \alpha-\tau \mu \dot{\eta}^{\prime}$ in 21:26). ${ }^{35}$ Moreover, John may also have in mind Zechariah 14:16-19, where the nations make a perpetually annual trek to Jerusalem in the future to participate in the celebration of the Feast of Tabernacles (v. 18). As Aune observes, in Revelation 21:24, 'full participation in eschatological salvation is presupposed'. ${ }^{36}$

Perhaps the most significant change that John has introduced into

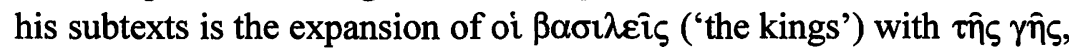
attaching greater significance to the nations and kings from Isaianic texts. This designation has precedents in the OT, the two most important texts being Psalm 2:2 (מלכי־ארץ) and Isaiah 24:21 (מלכי האדמה על־האדמה), 3 (מלה both of which portray the kings in decidedly negative terms. According to Psalm 2:2 the kings of the earth, along with the nations, are those who conspire against God's anointed one, 'take their stand ... against the Lord' and are the objects of God's wrath (2:4-5). In Isaiah 24:21 the kings of the earth, along

35 It is possible to construe the ostensible 'conversion' of the nations here as forced confession and acknowledgment after the pattern of texts such as Phil. 2:10-11 (cf. Eph. 1:21-22). I am grateful to Dr Craig Blomberg, who suggested this possibility to me in private communication. Phil. 2:10-11 constitutes an allusion to Is. 45:23, which refers to the involuntary worship of God by all creation (contra G. Hawthorne, Philippians [WBC 43; Waco, TX: Word, 1983], pp. 93-95). Other texts in Isaiah also seem to envision involuntary worship of God by the nations and kings $(41: 20 ; 49: 7,23 ; 52: 15 ; 60: 11 ; 66: 18-24)$. This would alleviate the tension noted in this article created by universal scenes of judgement and 'worship'. However, as the above analysis has shown, mere 'forced worship' does not do justice to John's use of Is. 2:2-5, nor to the doxological language in $21: 24$. The nations are converted to become the true people of God (cf. 21:3) and to render God worship.

36 Aune, Revelation 17-22, p. 1172. Thus, G.W. Buchanan is incorrect when he concludes that John expects Gentiles to become Jewish converts (The Book of Revelation: Its Introduction and Prophecy [The Mellen Bible Commentary NT Series, 22; Lewiston: Mellen Biblical Press, 1993], p. 597).

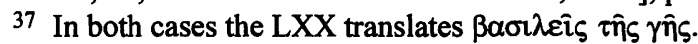


with the powers of heaven, are recipients of divine punishment on the day God comes to Zion and manifests his glory (vv. 22-23).

The use of the phrase 'kings of the earth' earlier (Rev. 1:5; 6:15; $17: 2,18 ; 18: 3,9 ; 19: 19)$ provides the precedent for understanding $21: 24$. The category 'kings of the earth' is utilised predominantly in a negative manner (except for 1:5) to depict those in opposition to God and his rule and who align themselves with the beast and his dominion and are objects of diving punishment (in 19:19-20 the kings of the earth are destroyed at the Parousia of the Lamb). Their presence in the New Jerusalem vision forges an antithesis to the Babylon vision of chapters 17-18, where the kings of the earth aligned themselves under the dominion of Babylon $(17: 2,18 ; 18: 3,9)$. Thus, in contrast to their former role of giving idolatrous allegiance to the beast, the kings of the earth now enter the New Jerusalem and give God glory (cf. 15:4). ${ }^{38}$

As J. Fekkes has correctly observed, both of these categories, the nations and the kings of the earth, are 'collective symbols designating those formerly in opposition to God's kingdom' so that they remain political and not just spiritual designations: kings of the earth-see above; nations-2:26; 11:2, 18; 12:5; 14:8; 15:3-4; 16:19; 18:3, 23; $19: 15 ; 20: 3,8 ; 21: 26 ; 22: 2.39$ Once again, these earlier uses provide the hermeneutical antecedents for the presence of the nations and kings of the earth in $21: 24$, so that now the nations and kings of the earth, formerly in compliance with Babylon and the beast, come to the New Jerusalem to render allegiance to God in fulfilment of Isaiah $2: 2-5 ; 60$.

Consequently, the presence of the nations and kings of the earth in Revelation 21:24 is more than just a reference to the transcultural makeup of the church composed of diverse peoples and ethnic groups throughout history (5:9). 40 Rather, the above analysis suggests that

38 See also G.R. Beasley-Murray, Revelation (NCBC; Eerdmans: Grand Rapids; London: Marshall, Morgan \& Scott, 1974), p. 328; Bauckham, Climax, p. 314, followed by P. Lee, The New Jerusalem in the Book of Revelation (WUNT, 129; Tübingen: Mohr Siebeck, 2001), pp. 288-89.

39 Fekkes, Isaiah and Prophetic Traditions, p. 269 n. 124. See also Bauckham, Climax, p. 314. Contra U. Sim, Das himmlische Jerusalem in Apk 21,1-22,5 im Kontext biblish-jüdischer Tradition und antiken Städtbaus (BAC 25; Trier: Wissenschaftlicher Verlag, 1966), p. 122.

40 Cf. Beale, Revelation, p. 1101; Gundry, 'People as Place', p. 263. The use of غ̇к ('out of', 'from') with tribe, language, people and nation does seem to point to the transcultural makeup of the people of God $(5: 9$; cf. 7:9). Yet the phrase is sufficiently general enough not to require notions such as 'individuals taken out of' so that a large segment is left for judgement and only a small remnant left for 
firstly the conversion of the kings and nations in 21:24 (which is contiguous with the restored Jerusalem, 21:2) is a future one, semantically consistent with Isaiah $2: 2-5 ; 60: 3$, and not just a succinct reference to the nations and kings who become God's people throughout history as Beale and others maintain, and secondly the nations and kings of the earth depict those who were formerly in opposition to God and his rule, not just those who replace them. Therefore, in addition to the OT people of God indicated by the twelve gates named after the twelve tribes of Israel (21:12) and the NT people of God indicated by the twelve foundations inscribed with the twelve apostles, the reader is meant to distinguish a third group: the nations who will be converted in the future in fulfilment of the OT prophecies (Is. 2:2-5; 60) will also inhabit the new Jerusalem and become, along with the former two groups, the one people of God (21:24; cf. v. 3). As P. Lee comments, the gathering of the nations into the New Jerusalem functions '1) to complete God's purpose which is to redeem all the peoples in the world; 2) to emphasise the centrality and universality of the New Jerusalem'. ${ }^{41}$

The second difficulty which confronts the attentive reader is the apparent inconsistency of visions of total destruction (19:17-21; 20:7-10) and the vision of universal salvation (21:1-22:5). As Bauckham laments, most commentaries seem unable to account for both. ${ }^{42}$

As Aune observes, the place of the Gentiles in Jewish eschatological expectations could be delineated in four ways:

i) complete annihilation;

ii) the restoration of Israel to the expense of other nations;

iii) the subservience of the nations to Israel;

iv) the complete participation of the Gentiles in eschatological salvation. ${ }^{43}$

According to Aune, Revelation incorporates both i) (19:17-21) and iv) (21:24-26), though he ventures no suggestions as to how this apparent tension is to be construed, except for the fact that these two

salvation. See $B A G D$, pp. 234-35. Thus, while it would be wrong to see this phrase as implying the conversion of every last individual belonging to the group, it is likewise unnecessary to be more restrictive so that only a small part of the larger whole is envisioned as experiencing salvation. It is not John's concern to quantify his visions of salvation and judgement.

41 Lee, New Jerusalem, p. 287.

42 Bauckham, Climax, p. 242.

43 See the references cited in Aune, Revelation 17-22, p. 1172; cf. Ford, Revelation, p. 338. 
perspectives were so firmly embedded in apocalyptic tradition that they are included in John's scenario out of necessity.

Rissi and Vogelgesang provocatively suggest that this should be understood in terms of those who have experienced ultimate judgement in the lake of fire $(16: 16-21 ; 19: 17-21)$ now streaming into the New Jerusalem through it perpetually open gates (21:25). Rissi and Vogelgesang assume that, for the most part, John's spatial imagery should be understood in a fairly straightforward manner, so that the presence of the nations and the open doors in the New Jerusalem implies the entrance of the former through the latter following the final judgement. Yet it is questionable whether John's discourse should be taken in such a 'literal' manner. To be sure, though the Apocalypse is symbolic in essence, not everything is symbolic, and some things will be understood in a more straightforward manner. ${ }^{44}$ Thus, in the visions of judgement, nations and kings are real people, and the end-time judgement is a real judgement. However, John's takes over the spatial language of the prophets in his symbolic discourse to convey the fulfilment of their visions. As Beale remarks, "bringing glory" into the city in vv. 24 and 26 is spatial language, but it conveys a nonspatial notion'. ${ }^{45}$ Thus, the primary point of John's use of this imagery in not spatial, but to depict the fulfilment of the prophetic hope of the inclusion of the nations in eschatological salvation. ${ }^{46}$ Beyond the primary point of the imagery, it is unnecessary to push the language in a direction that the text itself does not warrant, since the warning of exclusion articulated in 21:27 qualifies vv. 24-26, clearly demonstrating that 'the city is not infinitely inclusive'. ${ }^{47}$

Bauckham insists on taking both sets of statements concerning universal judgement and salvation seriously, without forcing one set of statements to pre-empt the other. The

picture of universal judgment does not mean that the picture of the universal worship of God is not to be taken fully seriously, nor does the picture of the

44 On the symbolism in Revelation see Beale, Revelation, pp. 50-69; Bauckham, Theology, pp. 17-22.

45 Beale, Revelation, p. 1098. Cf. Gundry, 'People as Place', pp. 263-64;

J. Comblin, 'La liturgie de la Nouvelle Jérusalem (Ápoc xxi 1-xxii 5)', ETL 29

(1953), p. 25; R. Mounce, The Book of Revelation (NICNT; Grand Rapids: Eerdmans, 1977), p. 385.

46 Lee, New Jerusalem, p. 288.

47 C. H. Talbert, The Apocalypse: A Reading of the Revelation of John (Louisville: Westminster John Knox, 1994), p. 102. Cf. Müller, Die Offenbarung, p. 362. 
universal worship of God mean that the picture of universal judgment is not to be taken fully seriously. 48

But then Bauckham concludes that the vision of universal salvation explicated in Revelation 21:1-22:5 receives its 'theological priority' and 'supersedes all the visions of judgment', mitigating his initial observation. ${ }^{49}$ Thus, it appears that ultimately Bauckham fails to give equal weight to both perspectives, by privileging the visions of salvation over judgement.

As J. Webb Mealy has observed, 'up to Rev. 20.15, the readers have been given every reason to think that a significant portion of humanity will perish in a way that is total and irrevocable'.50 Moreover, residue from the judgement theme still reside in 21:8, 27. This means that the reader up to the very end is to keep the contrasting visions of universal judgement and universal salvation in creative tension. John envisions both large scale judgement and large scale salvation. How is the reader to account for both of these perspectives without silencing one or the other?

A more nuanced approach to handling the tension is adumbrated by Bauckham himself. He concludes that 'John seems content to place indications of the universal conversion of the nations alongside references in equally universal terms to final judgment'. In doing so he is 'painting pictures which each portray a valid aspect of the truth'. Moreover, 'the two pictures correspond to the choice presented to the nations' ${ }^{51}$ Yet Bauckham ultimately allows the vision of salvation to supersede and apparently override the visions of judgement. Rather, both widespread destruction and widespread salvation, drawn from the prophets, form part of the expectations catalogued in John's visionary denouement, though Revelation's symbolic world does not demand that its pictures be taken with literalness or as strictly logical.

Given the above analysis, the language of universal salvation and worship as it relates to the 'nations' and 'kings of the earth' functions within the author's metaphorical narrative in a rhetorical manner. Whereas the kings of the earth and nations once rendered their allegiance to Babylon and were under its dominion, now they come to the New Jerusalem to bring their tribute and to render absolute allegiance to God in fulfilment of Isaiah $2: 2-5 ; 60$. The universal dominion of Babylon is now transferred to God and the New

48 Bauckham, Climax, p. 309.

49 Bauckham, Climax, p. 318, italics mine.

50 Mealy, Resurrection and Judgment, p. 228.

51 Bauckham, Theology, pp. 102-106 
Jerusalem, fulfilling the angelic pronouncement in 11:15: 'The kingdom of this world has become the kingdom of our Lord and of Jesus Christ'.

But further, it is not John's purpose to quantify the outcome of scenes of universal judgement and salvation, but to emphasise the universal and comprehensive nature of God's judgement and salvation, providing a portrayal of the two valid aspects of the truth. Rather than allow the final vision of salvation to supersede or mitigate the visions of judgement as Bauckham does, both are allowed to stand in the text with equal force. Despite the striking reversal that takes place with the universal portrait of salvation (21:24-26), one must still give account for the equally potent vision of universal judgement $(19: 17-21 ; 20: 7-10)$. In this way, the visions of salvation and judgement function to emphasise the comprehensive nature of God's judgement and salvation. Moreover, these visions present the opposite options available to the nations, a conclusion confirmed by the warning of exclusion in v. 27.

While largely in agreement with Bauckham, Lee attempts to solve the tension by appealing to Revelation 5:9-10; 7:9.52 As a result of Christ's death and resurrection, even the rebellious nations can become the people of God, though not everyone of them will, since John only envisions those from (غ̇K) the tribes and nations being redeemed. Lee is correct in seeing 7:9 as a projection of and as parallel to vv. 24-26. But his approach, while demonstrating the possibility of the nations becoming the people of God, does not address the universal message of judgement displayed in chapters 19-20.

Moreover, this tension between universal salvation and universal judgement is a phenomenon already latent in John's OT sources and in apocalyptic literature, in which the topos of the conversion of the nations finds frequent expression. For example, similar to the function of John's imagery to present the opposite options available to the nations and kings, in Psalm 2:2 the kings are depicted as those who conspire against God and are the objects of his wrath (vv. 4-5). Yet Psalm 2:10-12 constitute a warning to the kings to yield to God's rule and avert his wrath, and apparently hopes for their turning to God: 'Serve the Lord with fear and rejoice with trembling' (v. 11). And Psalm 86:9 states that 'All the nations you have made shall come and bow down before you, O Lord, and shall glorify your name'.

52 Lee, New Jerusalem, pp. 287-88. 
Perhaps more than any other book in the prophetic corpus, Isaiah in particular contains a diversity of material relating to the destiny of the nations. ${ }^{53}$ On the one hand nations are denounced and are the objects of judgement $(24: 1,6,21 ; 41: 11-12,15-16 ; 44: 9-20 ; 45: 14$; $49: 23-24 ; 52: 1 ; 59: 18-19 ; 63: 1-6 ; 66: 16,24)$. Often the visions of judgement are far reaching and universal $(24: 1,6,21 ; 60: 12 ; 66: 16)$. On the other hand, Isaiah also contains oracles of salvation for the nations and portrays their participation in salvation $(42: 6 ; 45: 22 ; 49: 6$; $51: 5 ; 56: 6-7 ; 62: 2-3 ; 66: 18)$, often in equally universal terms $(25: 6-8 ; 66: 2-3,18)$.

What is significant is that both strands of John's imagery are drawn from the most universal strands of prophetic portrayals of the judgement and conversion of the nations:

Universal destruction: Ezekiel 38-39-Rev. 19:17-21; 20:7-10

Universal salvation: Is. 2:2-5; 60:3-Rev. 21:24-26.54

Furthermore, in 1 Enoch 90 images of universal destruction of the nations and salvation are similarly juxtaposed. Although the beasts of the field and birds of heaven are laid waste in 90:13-19, the sheep, animals and birds of heaven who had been destroyed are subsequently gathered into the house $(90: 30-36)$ which could not contain them all (90:34). Similarly, in Sibylline Oracles 3:657-731 the kings attack the temple in Jerusalem (3:657-68) but are subsequently annihilated by God (cf. Rev. 20:7-10). However, the inhabitants of all islands and cities will acknowledge God's sovereignty and worship him (3:710-31). Thus the juxtaposition of images of judgement and salvation couched in universal terms is also a feature Revelation shares with apocalyptic literature.

Bauckham's thesis could perhaps be sustained in analogy with statements such as Romans 11:26a, which envisions the salvation of 'all Israel', a corporate designation referring to the nations as a whole, without implying the salvation of every last individual (cf. Mt. 8:34). 55 Thus, the reference to the nations and kings in 21:24-26

53 See Davies, 'Destiny of the Nations', pp. 93-120; R.E. Clements, Prophecy and Tradition (Oxford: Basil Blackwell, 1975), pp. 58-72.

54 While Zechariah 14 clearly envisages scenes of widespread destruction and salvation in relation to the nations, it is also clear that it is the survivors of the nations (14:16) who had previously attacked Jerusalem and were subject to God's judgement who will come in a yearly trek to the New Jerusalem to celebrate the Feast of Tabernacles.

55 See J.D.G. Dunn, Romans 9-16 (WBC 38b; Dallas: Word, 1988), p. 681. In Mt. 8:34 $\pi \hat{\alpha} \sigma \alpha \dot{\eta} \pi$ ót $\iota_{\varsigma}$ most likely does not indicate that every last inhabitant of the city came out to oppose Jesus' actions, but that the city as a whole is in view. 
could be a corporate designation, referring to the nations and kings as a whole as Bauckham maintains, without necessarily implying the conversion of every last individual (21:27). However, given that the scenes of judgement and salvation should be permitted their full force, this fails to alleviate the tension created with the universal themes of judgement (chs. 19-20), for conversely one would have to also claim that the nations and kings as a whole will be judged, while some individuals would experience consummate salvation.

In summary, John's inclusion of the 'nations' and 'kings of the earth' in eschatological salvation functions in such a way as to suggest that those who formerly worshipped the beast and opposed God's kingdom now come to the New Jerusalem to give God glory. The absolute transfer of sovereignty from the beast to God and the Lamb is accompanied by a corresponding shift in allegiance. The picture of the inclusion of the nations to become incorporated into the one people of God signifies the fulfilment of the Isaianic promise of a future conversion of the nations and restoration of Jerusalem as the centre of a universal Völkerwallfahrt (Is. 2:2-5; 60:3). Thus, in constructing his own vision of eschatological salvation, John combines the most universal strands of expectations of both judgement and salvation from the prophets in order to show their fulfilment in chapters 19-21.

Furthermore, the tension created by the universal vision of salvation in 21:1-22:5 with universal visions of judgement (cf. $19: 17-21 ; 20: 7-10)$ within the contours of John's vision serves a rhetorical purpose of highlighting the comprehensive nature of God's sovereignty in bringing about judgement and salvation. The antithetical portraits of judgement and salvation serve to present the opposite options that are available to the nations: punishment for those who refuse to repent; salvation for those who repent (cf. v. 27), without quantifying the outcome (it would be inappropriate to ask what percentage will fall under the category of judgement or salvation, or which will include more).

\section{c) Revelation 22:2}

The final explicit mention of the nations occurs in $22: 1-5$, where the New Jerusalem vision shifts to accommodate imagery evocative of paradise (Ezk. 47:1-12; cf. Gn. 2:9-10).

[There is] the tree of life bearing twelve fruits, giving its fruit each month, and the leaves of the tree are for the healing ( $\left.\theta \varepsilon p \alpha \pi \varepsilon^{i} \alpha v\right)$ of the nations ( $\tau \hat{\omega} v$ $\dot{\varepsilon} \theta v \omega \hat{v}$ ). (Rev. 22:2) 
Their leaves will not wither nor their fruit fail, but they will bear fresh fruit every month ... Their fruit will be for food, and their leaves for healing (לתרופה (Ezk. 47:12)

Once again John introduces a significant change to his OT allusion. Whereas Ezekiel 47:12 stipulates that the leaves of the trees will be for healing, Revelation 22:2 specifies that the healing is for $\tau \hat{\omega} \mathrm{v}$ $\dot{\varepsilon} \theta \vee \omega \hat{~}{ }^{57}$ Significantly, it appears that the author of Revelation 22:2 has exploited the Ezekielian distinction between the fruit (פריו) and leaves (עלהו) (Ezk. 47:12) in order to once again combine a reference to the particular covenant people (twelve fruits) and the inclusion of the nations (leaves for healing), both participating in eschatological life. This suggests that the healing depicted here should be seen as more than the universal makeup of the church, but once again as a reference to the end-time conversion of the nations to become the one people of God in line with 21:24-26. Aune is insensitive to the broader context of Revelation 21:1-22:5 when he concludes that 'the allusion is simply mechanical, however, since there is no real place in the eschatological scheme of Revelation for the "healing of the nations" construed as their conversion'. .58

This healing, furthermore, should be seen in contrast to the former depiction of the nations as those who followed the beast and contested God's kingdom. 59 They now come to the New Jerusalem and experience paradisal life. Consequently, with the mention of the nations here in John's eschatological scenario the OT expectation of the eschatological inclusion and conversion of the nations is once again presupposed, if not overtly depicted.

Moreover, contextually the statement which follows in 22:3 should be conjoined with 22:2.60 Thus, the promise that there would no longer be a ban of destruction ( $\kappa \alpha \dot{\tau} \dot{\theta} \varepsilon \mu \alpha)$ suggests that the nations

56 The LXX renders לתרופה with íricı

57 On the changes made to Ezk. 47:12 see A. Vanhoye, 'L'utilisation du livre d'Ézéchiel dans l'Apocalypse', Bib 43 (1962), 470-71; Beale, 'Revelation', p. 328.

58 Aune, Revelation $17-22$, p. 1178 . There is some disagreement as to the precise identification of the healing in Ezk. 47:12 and Rev. 22:2. Rabbinic interpretation of Ezk. 47:12 understood the healing provided by the leaves to consist of fluency of speech in speaking the words of the Torah (Deut. $R$. 1:1) or other physiological benefits (such as overcoming dumbness or barrenness in women; cf. Song. $R$. 4:12; b. men. 98a). Given the context of 'life' (Rev. 22:1), it is likely that the reader of Rev. 22:2 should understand the healing, not as a reference to a specific malady, but more broadly as life and as freedom from the effects of sin which plague the old order (cf. 21:4).

59 Cf. Sim, Das himmlische Jerusalem, p. 131.

60 Bauckham, Climax, p. 316. Beale, Revelation, p. 1112. 
who now dwell in the New Jerusalem and have been healed of idolatry and $\sin (22: 2)$ need never fear the destruction God has decreed for rebellious nations (22:3). The OT matrix for the к $\alpha \dot{\alpha} \theta \varepsilon \mu \alpha$ of 22:3 is the חרם of Zechariah 14:11:

And they shall dwell in it, and there shall never again be a ban of destruction

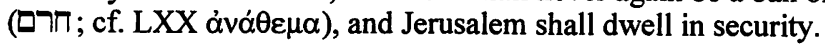

Growing out of the context of holy war, the noun form of חרם could mean a 'ban of destruction', that is, God's decree that his enemies be completely destroyed. ${ }^{61}$ In Zechariah 14:11 the eschatological Jerusalem need never again fear God's judgement and destruction at the hands of hostile nations (cf. Jos. 7:12). In addition, Bauckham points to a parallel in Isaiah $34: 2$, with its overt reference to God's ban upon all the nations. ${ }^{62}$

For the Lord is enraged against the nations, and furious against all their hoards; he has doomed them (החרימם), has given them over for slaughter.

The significance of this allusion and its nexus with the preceding verse would be that the nations who have experienced healing from sin (22:2) need no longer fear God's ban of destruction on them, since the nations will no longer resist the rule of God. However, the clear allusion to Zechariah 14:11 indicates that the ban of destruction is lifted for the entire New Jerusalem, so that all those who enjoy eschatological life there, including the nations, need never again fear destruction, but will dwell there in perpetual security. As this relates to the position of the nations in the New Jerusalem, it functions in antithesis to the vision of the nations as the recipients of divine judgement and destruction in 19:17-21;20:7-10. As with $21: 24$, the author does not privilege one perspective over then other, nor quantify the visions with a percentage of those of the nations who belong in each category. Rather, the contrast is once again rhetorical: to depict the complete and universal transference of the kingdom from the beast and Babylon to God and the New Jerusalem and the comprehensive nature of God's judgement and salvation. This, then, entails the concomitant enjoyment of eschatological life for the nations and the

61 Cf. N. Lohfink, 'חרם', TDOT, V, pp. 180-99; M. Weinfeld, 'Deuteronomy, Book of', $A B D$, II, pp. 179-80; Ford, Revelation, p. 362; Bauckham, Climax, p. 316; Beale, Revelation, pp. 1112-13; Aune, Revelation 17-22, p. 1179. Cf. Lv. 27:27-28; Dt. 7:2, 20; Jos. 6:17-18; 7:12; 1 Sa. 15:3, 21; 1 Ki. 20:42. The LXX translates several of these with ávó $\theta \varepsilon \mu \alpha$. According to H.B. Swete, John's $\kappa \alpha \tau \dot{\theta} \theta \varepsilon \mu \alpha$ is probably a stronger term (The Apocalypse of St. John [3rd edn; London: Macmillan, 1911], p. 296).

62 Bauckham, Climax, p. 317. 
removal of the curse which rested upon those who were formerly antagonistic toward God's dominion (chs. 17-18).

\section{Conclusion}

The burden of this essay has been to attempt to account for the presence of the nations in Revelation 21:1-22:5 when the author has previously narrated their rebellion and demise in chapters 16 to 20 . In doing so I have attempted to offer a solution to the tension different from previous attempts. With Bauckham functioning as an important dialogue partner, the conclusions reached here register both agreement and disagreement with Bauckham's overall approach. In agreement with Bauckham, it is incumbent on the interpreter to give equal weight to both perspectives of universal judgement and salvation. But Bauckham seems to tilt the balance in favour of universal salvation when he concludes that the vision of salvation in $21: 3,24-26 ; 22: 2$ supersedes the visions of judgement. But both statements of universal rebellion-judgement and salvation stand in the texture of Revelation's visions in seemingly incongruent fashion. Rather than privileging one perspective (judgement, salvation) over the other, as Bauckham and several other approaches are inclined to do, this article has suggested that the reader should leave both perspectives in tact and allow each to receive a fair hearing.

In this regard, this article has attempted to establish two points. First, in agreement with Bauckham, the inclusion of the nations in Revelation's end-time scenario semantically evokes OT prophetic expectations of the eschatological conversion of the nations to worship God (Is. 2:2-5; 60). Given the pervasive influence of the OT in John's own discourse, it is natural that the author of Revelation would include a reference to a common topos of apocalyptic and prophetic expectation: the New Jerusalem as a centre of a universal Völkerwallfahrt and the conversion of the nations to worship the true God. Thus, it is not merely a shorthand reference to the transcultural makeup of the church. Those who previously rendered allegiance to the beast and oppressed God' people now come to restored Zion to worship the true God. The transference of the kingdom from the beast to God is now accompanied by a corresponding transference of allegiance.

Second, in an attempt to implement what is a more consistent application of Bauckham's own observations, I have ventured that the tension created by the presence of statements of universal judgement $(19: 17-21 ; 20: 7-10)$ and universal salvation $(21: 3,24-26 ; 22: 2)$ as it 
relates to the destiny of the nations functions in a rhetorical manner: to portray the opposing options confronting the nations and to depict the comprehensive and universal nature of judgement and salvation in the establishment of God's kingdom. Johns envisions both wide scale judgement and wide scale salvation. Thus, it is methodologically unnecessary to privilege salvation over judgement so that the latter is muted. John has drawn on the most universal strands from the OT prophets of both judgement and salvation to envision the ultimate fulfilment of prophetic hopes. Thus, John depicts the world from the two aspects of judgement for refusal to repent and submit to God's reign and salvation for those who repent. Bauckham is in part correct when he suggests that the vision of salvation receives 'theological priority' in that this is the ultimate direction in which the text moves. However, it is the thesis of this paper that the interpreter is still forced to deal with the fact that the judgement in chapters 19-20 is also universal and final. In my judgement it is unclear what Bauckham means when he concludes that the vision of salvation supersedes visions of judgement. He may only mean that it receives primary importance in John's vision. But if he implies that the visions of salvation mitigate or cancel out the visions of judgement, it is hard to see how Bauckham escapes his own concern that commentators seem unable to give equal weight to both perspectives.

The transfer of sovereignty from the beast to God and the Lamb does not suggest that judgement is superseded or overturned. Neither does it suggest that the nations are simultaneously destroyed and then redeemed. Rather, the author appeals to the most universal strands from the OT of both judgement and salvation to show what is at stake and to depict the comprehensive nature of God's judgement and salvation in presenting the options available to the nations. In fulfilment of OT hopes, the New Jerusalem will become a centre of a world-wide Völkerwallfahrt, yet the author is not interested in quantifying the outcome, or privileging one perspective over the other. Rather, John allows visions of both universal judgement and salvation to stand in tension in presenting the options for the nations who rebel or repent. What is ultimately required in any reading of John's visions is a sensitivity to the OT matrix of John's imagery and its semantic import, as well as the way in which the imagery functions within the discourse of John's own unique vision. 